\section{Ekstrak Daun Kelor (Moringa Oleifera Lamk) dalam Menurunkan Kadar Glukosa Darah pada Tikus (Rattus novergicus)}

\author{
Mursito, S. \\ Bialangi Lilies \\ Hayyatun Mawaddah
}

\begin{abstract}
Abstrak. Tujuan penelitian ini adalah: 1) memperoleh informasi manfaat ekstrak daun kelor yang memiliki efektifitas dalam menurunkan kadar glukosa darah. khususnya pada R.norvegicus, 2) memperoleh informasi tentang konsentrasi ekstrak daun M. oleifera) memiliki efektifitas dalam menurunkan kadar glukosa darah, khususnya pada R.norvegicus, Penelitian dilakukan di Laboratorium Program Studi Pendidikan Biologi FKIP Universitas Tadulako pada Bulan Mei sampai Agustus 2018, dan merupakan penelitian eksperimen dengan metode RAL. Variabel bebas dalam penelitian ini adalah ekstrak daun M. oleifera, dan variabel terikat adalah kadar glukosa pada $R$. Norvegicus. Analisis data dalam penelitian ini dilakukan dengan menggunakan, analisis data kuantitatif Anava dengan bantuan SPSS Versi 18.Hasil analisis sidik ragam (anava) diperoleh nilai signifikansi sebesar $0.000<\alpha(0.05)$, yang berarti menolak Ho dan menerima $\mathrm{H}_{1}$. Dengan demikian maka dapat dijelaskan bahwa ekstrak daun kelor berpengaruh nyata terhadap penurunan kadar glukosa darah pada tikus ( $R$. governicus). Jika dilihat pada hasil analisis uji lanjut menggunakan uji Duncan maka konsentrasi terbaik dalam menurunkan kadar glukosa tersebut adalah pada perlakuan M4, dengan nilai hasil uji Duncan yang berbeda dari yang lainnya, yaitu sebesar 113.40.

Kata kunci: moringa oleifera lamk, glukosa darah, Rattus novergicus.
\end{abstract}

\section{Pendahuluan}

Moringa oleifera atau di Indonesia dikenal dengan nama kelor telah sejak dulu digunakan sebagai obat tradisional, baik dalam bentuk segar maupun dalam bentuk ramuan berupa jamu. Kelor di kenal dengan berbagai nama di setiap negara seperti moringa, ben-oil tree, clarifier tree, drumstick tree (Inggris), kelor, marunggai, sajian (Malaysia), marum (Thailand), serta malunggay (Filipina). Di Indonesia kelor juga dikenal dengan berbagai nama seperti kelor (Jawa, Sunda, Bali, dan Lampung), kerol (Buru), maronggih (Madura), moltong (Flores), kelo (Gorontalo), keloro (bugis), kawano (Sumba), ongge (Bima) dan hau fo (Timor)

Tanaman kelor (Moringa oleifera) sudah dikenal luas di Indonesia, khususnya di daerah pedesaan, tetapi belum dimanfaatkan secara maksimal dalam kehidupan. Di Indonesia pohon kelor banyak ditanam sebagai pagar hidup, ditanam disepanjang ladang atau tepi sawah, berfungsi sebagai tanaman penghijauan. Selain itu tanaman kelor juga dikenal sebagai tanaman obat berkhasiat dengan memanfaatkan seluruh bagian dari tanaman kelor mulai dari daun, kulit batang, biji,hingga akarnya (Simbolan, dkk., 2007). Melo, et el (2013); Nweze \& Nwafor (2014); Shiriki, et el (2015), daun kelor kering per100g mengandung air 0,041\%, 2,050\% kalori, 3,073\% karbohidrat, 0,28\% protein,

\section{BIONATURE}

\author{
p-ISSN 1411 - 4720 \\ e-ISSN 2654 - 5160
}

Abstract. The purposes of this study were: 1) obtain information on the benefits of Moringa leaf extract which has the effectiveness in reducing blood glucose levels. specifically on Rattus norvegicus, 2) obtaining information about the concentration of Moringa oleifera leaf extract) has effectiveness in reducing blood glucose levels, specifically on Rattus norvegicus. Research conducted in the Laboratory of Biology Education Study Program at the Tadulako University FKIP in May until August 2018 and is an experimental study using the RAL method. The independent variable In this study was Moringa oleifera leaf extract, and the dependent variable was the glucose level on Rattus Norvegicus. Data analysis in this research was carried out using, analysis of quantitative Anava data with the help of SPSS Version18. Significant results of an analysis of variance

(ANAVA) obtained a significance value of $0,000<\alpha(0.05)$, which means

rejecting Ho and accepting H1. Thus it can be explained that Moringa leaf

extract has a significant effect on the reduction in blood glucose levels in rats

(Rattus governors). When seen in the results of the analysis of the advanced

test using the Duncan test, the best concentration in reducing glucose levels is on the M4 treatment, with Duncan test results that are different from the other, amounting to 113.40 .

Keywords: moringa oleifera lamk, blood glucose, rattus novergicus.

Mursito, S Universitas Tadulako Indonesia

Bialangi Lilies Universitas Tadulako Indonesia

Hayyatun Mawaddah Universitas Tadulako Indonesia 
0,027\% lemak, 0,126\% serat,20,03\% kalsium, 22\% dan 7,95\% kadar abu. Tanaman kelor (Moringa oleifera) dikenal sebagai mother's best friend dan miracle tree (Ashfak, et el., 2012). Seluruh bagian tanaman ini dapat dimanfaatkan menjadi sesuatu yang berguna, dimulai dari makanan, obat, kosmetik, bahkan pemurni air (biji).

Tanaman Kelor (Moringa oleifera Lamk.) telah dikenal selama berabad-abad sebagai tanaman multi guna, padat nutrisi dan berkhasiat obat. Mengandung senyawa alami yang lebih banyak dan beragam dibanding jenis tanaman lainnya yang ada. Tanaman Kelor mengandung 46 antioksidan kuat yang melindungi tubuh dari radikal bebas. Kelor memiliki banyak manfaat bagi manusia. Semua bagian dalam tanaman kelor bisa dimakan dan mengandung senyawa penting yang bermanfaat bagi tubuh. Untuk bagian daun kelor banyak dimanfaatkan khususnya di kamboja, Filiphina, India selatan dan Afrika. Di Indonesia sendiri sudah ada tempat khusus budidaya kelor yang juga telah memproduksi tepung kelor premium dan berbagai produk kesehatan berbahan dasar kelor diantaranya teh kelor, kapsul kelor dan sampo kelor (Krisnadi,2015).

Daun kelor mengandung Kandungan asam askorbat, ß-karoten, asam tocopherol, flavonoid, fenolat, karotenoid, derivat asam hidroksinamit, dan flavonoid menyebabkan daun kelor dapat digunakan sebagai sumber bahan alami antioksidan (Krisnadi, 2015; Jadoon, et el., 2015 dalam Sugihartini dan Nuryanti, 2017). Di beberapa daerah tertentu seperti di Flores (NTT) dan Madura, masyarakat menggunakan tepung daun kelor yang dicampurkan dengan bedak dengan maksud untuk menghilangkan flek/noda hitam (pigmentasi) pada wajah yang diduga muncul akibat adanya faktor peningkatan usia, radikal bebas dan adanya paparan langsung dengan sinar matahari. Hingga saat ini di Indonesia belum ada pengujian efektifitas antioksidan dan antiaging yang terdapat pada kelor, sehingga penelitian ini perlu dilakukan. Antioksidan adalah senyawa kimia yang dapat menyumbangkan satu atau lebih elektron kepada radikal bebas, sehingga radikal bebas tersebut dapat diredam (Suhartono, 2002). Antioksidan memasok atom bebas yang dibutuhkan oleh tubuh manusia, juga mengurangi efek radikal bebas.

Masyarakat pada umumnya sedikit memahami manfaat daun kelor untuk kesehatan. Daun kelor dalam pembuatan teh sangat bermanfaat untuk kesehatan karena mengandung kandungan flavonoid sebagai antioksidan dan anti inflamasi. Daun kelor mengandung dua jenis zat bioaktif yaitu quercetin dan kaempherol. Penelitian lain yang dilakukan oleh Wahyuni, dkk (2013) melaporkan bahwa daun M. oleifera mengandung zat kimia,seperti minyak behen, minyak terbang, emulsin, alkaloida, pahit tidak beracun serta vita-min A, B1, B2, dan C. Selain itu M. oleifera juga mengandung lebih dari 90 nutrisi 48 jenis antioksidan 36 senyawa anti inflamasi sehingga dapat digunakan sebagai obat herbal untuk penyembuhan Hepatitis B. Ekstrak daun $M$. oleifera memiliki efek protektif yang kuat terhadap toksisitas testis yang diinduksi oleh Dex dan karenanya mungkin berguna secara klinis (El-Wasimy, dkk., 2014).

Studi yang dilakukan oleh Charoensin (2014) membuktikan bahwa ekstrak daun $M$. oleifera memiliki aktivitas antioksidan, serta sifat sitotoksik dan kemopreventif. Oleh karena itu, mungkin bermanfaat sebagai tanaman obat untuk obat anti kanker alternatif baru dan produk nutraceutical. Hal tersebut ditunjukkan oleh hasil uji ekstrak metanol menunjukkan aktivitas radikal bebas yang lebih tinggi daripada ekstrak diklorometana (IC50 $=1,60 \pm 0,03 \mathrm{mg} / \mathrm{ml}$ dalam uji DPPH dan IC50 = 1,02 $\pm 0,06 \mathrm{mg} / \mathrm{ml}$ dalam uji ABTS). Dalam uji anti proliferatif, IC50 ekstrak diklorometana bervariasi dari 112 hingga $133 \mu \mathrm{g} / \mathrm{ml}$ untuk sel kanker HepG2, Caco-2 dan MCF-7, tetapi menjadi lebih dari $250 \mu \mathrm{g} / \mathrm{ml}$ untuk ekstrak metanol. Dalam uji chemopreventive, ekstrak diklorometana memiliki kapasitas untuk menginduksi aktivitas QR secara signifikan (nilai $C D=91,36 \pm 1,26 \mu \mathrm{g} / \mathrm{ml}$ ), sedangkan ekstrak metanol tidak memiliki efek induktif. Kelor berpotensi pula sebagai bahan baku dalam industri kosmetik, obat-obatan dan perbaikan lingkungan yang terkait dengan cemaran dan kualitas air bersih. Senyawa 
bioaktif dalam kelor menyebabkan kelor memiliki sifat bahwa daun kelor mengandung antioksi dan tinggi dan anti mikrobia. Hal ini menyebabkan kelor dapat berfungsi sebagai pengawet alami dan memperpanjang masa simpan olahan berbahan baku daging yang disimpan pada suhu $4^{\circ} \mathrm{C}$ tanpa terjadi perubahan warna selama penyimpanan. Kandungan nutrisi mikro sebanyak 7 kali vitamin C jeruk, 4 kali vitamin A wortel, 4 gelas kalsium susu, 3 kali potassium pisang, dan protein dalam 2 yoghurt. Oleh karena itu kelor berpotensi sebagai minuman probiotik untuk minuman kesehatan, atau ditambahkan dalam pangan gizinya. Selain daun dan buah, biji kelor juga dapat diolah menjadi tepung atau minyak sebagai bahan baku pembuatan obat dan kosmetik yang bernilai bernilai tinggi. Di samping itu fungsinya sebagai koagulans dan penjernihan air permukaan (air kolam, air sungai, air danau sampai ke air sungai).

Melalui fungsi dan manfaat kelor yang sangat banyak dan sangat baik untuk pangan, obat-obatan, maupun lingkungan maka sangat perlu pengembangan dan pengolahan yang kimia sehingga menghasilkan produk yang kompetitif dan bernilai jual tinggi. Kandungan. Salah satu khasiat kelor yang diyakini masyarakat adalah sebagai pengontrol dan menurunkan kadar gula dalam darah. Dalam hal ini sebagai obat penyakit diabetes mellitus. Kandungan senyawa flavonoid dalam bentuk terpenoid yang terdapat pada kelor merupakan senyawa yang sangat efektif dan lebih aman dalam penurunan kadar gula darah dibanding obat kencing manis yang biasa diresepkan dokter (Dewiyeti dan Hidayat, 2015).

Penelitian ini dilakukan untuk mendeskripsikan efektifitas ekstrak daun kelor ( $M$. oleifera) dalam menurunkan kadar glukosa darah pada tikus (Rattus novergicus) dan untuk mendeskripsikan konsentrasi ekstrak yang paling efektif dalam menurunkan kadar glukosa darah tersebut.

\section{Metode Penelitian}

\section{Jenis Penelitian}

Penelitian ini merupakan penelitian deskriptif kuantitatif dengan menggunakan metode eksperimen, yang dilakukan di Laboratorium Program Studi Pendidikan Biologi Universitas Tadulako, pada bulan Mei-Agustus 2018. Variabel penelitian ini terdiri dari variabel independen yaitu ekstrak daun kelor ( $M$. oleifera) dan variabel dependen yaitu kadar gula darah tikus (Rattus novergicus).

\section{Metode Penelitian}

Rancangan penelitian menggunakan metode rancangan acak lengkap (RAL) 1 faktor dengan 4 taraf perlakuan dan 3 kali pengulangan. Populasi yaitu seluruh hewan uji yang digunakan sebanyak 18 ekor sedangkan sampel merupakan sampel jenuh atau sampel populasi.

\section{Teknik Pengumpula Data}

Teknik pengumpulan data dilakukan dengan melakukan pengamatan dan uji terhadap kadar glukosa darah $R$. novergicus yang diinduksi dengan larutan gula pasir dan pemanis buatan baik pada kontrol maupun perlakuan yang diberi ekstrak dan kelor. Data juga dikumpulkan melalui uji terhadap konsentrasi yang paling efektif dalam menurunkan kadar gula darah pada $R$. novergicus. Analisis data dilakukan menggunakan teknik analisis statistik sidik ragam (Anava). 


\section{Hasil dan Pembahasan}

Data hasil penelitian ini diperoleh melalui data awal, data setelah induksi larutan sari manis dan gula pasir serta data setelah pemberian ekstrak daun kelor pada hewan uji, yaitu tikus putih (Ratus Norvegicus). Rerata data hasil penelitian disajikan pada Tabel 1 berikut.

Tabel 1. Data Hasil Penelitian

\begin{tabular}{|c|c|c|c|}
\hline Perlakuan & $\begin{array}{c}\text { Glukosa } \\
\text { Awal }\end{array}$ & $\begin{array}{c}\text { Glukosa } \\
\text { Induksi }\end{array}$ & $\begin{array}{c}\text { Glukosa } \\
\text { Akhir }\end{array}$ \\
\hline M0 & 75.0 & 9.8 & 74.5 \\
\hline M1 & 79.2 & 153.0 & 123.4 \\
\hline M2 & 92.4 & 165.0 & 79.8 \\
\hline M3 & 78.0 & 160.2 & 78.6 \\
\hline M4 & 83.4 & 199.8 & 86.4 \\
\hline M5 & 69.6 & 163.2 & 104.4 \\
\hline
\end{tabular}

Selanjutnya data tersebut dilakukan analisis statistik dengan menggunakan analisis sidik ragam dengan berbantukan aplikasi SPSS for windows 18. Hasil analisis data disajikan pada Tabel 2 berikut:

Tabel 2. Hasil Analisis Statistik

\begin{tabular}{|c|c|c|c|c|c|}
\hline \multicolumn{7}{|c|}{ Tests of Between-Subjects Effects } \\
\hline Source & $\begin{array}{c}\text { Type III Sum } \\
\text { of Squares }\end{array}$ & df & $\begin{array}{c}\text { Mean } \\
\text { Square }\end{array}$ & F & Sig. \\
\hline $\begin{array}{c}\text { Corrected } \\
\text { Model }\end{array}$ & $14809.084^{\mathrm{a}}$ & 5 & 2961.817 & 15.879 & .000 \\
\hline Intercept & 88144.009 & 1 & 88144.009 & 472.549 & .000 \\
\hline perlakuan & 14809.084 & 5 & 2961.817 & 15.879 & .000 \\
\hline Error & 2238.347 & 12 & 186.529 & & \\
\hline Total & 105191.440 & 18 & & & \\
\hline $\begin{array}{c}\text { Corrected } \\
\text { Total }\end{array}$ & 17047.431 & 17 & & & \\
\hline
\end{tabular}

Hasil analisis sidik ragam (anava) diperoleh nilai signifikansi sebesar $0.000<\alpha(0.05)$, yang berarti menolak Ho dan menerima $\mathrm{H}_{1}$. Dengan demikian maka dapat dijelaskan bahwa ekstrak daun kelor berpengaruh nyata terhadap penurunan kadar glukosa darah pada tikus $(R$. governicus). Jika diliat pada hasil analisis uji lanjut menggunakan uji Duncan maka konsentrasi terbaik dalam menurunkan kadar glukosa terssebut adalah pada perlakuan M4, dengan nilai hasil uji Duncan yang berbeda dari yang lainnya, yaitu sebesar 113.40.

Penelitian ini dilakukan dengan melakukan uji efektivitas penggunaan ekstrak daun kelor (Moringa oleifera) dalam menurunkan kadar glukosa darah tikus (Ratus governicus) yang diinduksi dengan larutan sari manis yang dicampur dengan larutan gula murni. Pemberian larutan sari manis dan gula murni pada hewan uji dilakukan selama 2 minggu dengan cara menjadikan larutan tersebut sebagai air minum bagi hewan uji. Hewan uji 18 ekor dibagi dalam 6 kelompok perlakuan dan 3 kali pengulangan, yaitu : 1) Mo sebagai control positif hanya diberi pakan dan minum, 2) M1 diberi pakan dan larutan pemanis buatan dan gula, M3) M2 diberi pakan + larutan pemanis buatan dan gula + ekstrak daun kelor 25\%, 4) M3 diberi pakan + larutan pemanis buatan dan gula + ekstrak daun kelor 50\%. 5) M4 diberi pakan + larutan pemanis buatan dan gula + ekstrak daun kelor 75\%,6) M5 diberi pakan + larutan pemanis buatan dan gula + ekstrak daun kelor 100\% Berdasarkan Tabel 1, menunjukkan bahwa terjadi 
Ekstrak Daun Kelor (Moringa Oleifera Lamk) dalam Menurunkan Kadar Glukosa Darah pada Tikus (Rattus novergicus)

(hlm. 6-12)

kadar peningkatan kadar glukosa darah yang cukup tinggi setelah pemberian larutan pemanis buatan dan gula yang dilakukan selama 2 minggu. Selanjutnya setelah pemberian ekstrak daun kelor selama 3 hari kadar glukosa darah pada hewan uji mengalami penurunan. Apabila mengacu pada hasil analisis statistik yang dilakukan dengan menggunakan analisis varian sederhana, diperoleh nilai signifikansi < dari $\alpha(0.05)$. Hasil tersebut menjelaskan bahwa ekstrak daun kelor memiliki efektivitas dalam menurunkan kadar glukosa darah pada tikus putih ( $R$. governicus). Selanjutnya pada uji lanjut menggunakan uji Duncan diperoleh bahwa perlakuan M4 dengan konserntrasi ekstrak daun kelor sebesar 75\% memiliki efektivitas yang lebih baik dari konsentrasi ekstrak lainnya.

Kemampuan daun kelor dalam menurunkan kadar glukosa darah dapat terjadi, karena daun kelor terdapat kandungan sel yang tinggi sebagai mineral penting dalam pembentukan insulin dalam mengontrol kadar glukosa dalam darah. Isnan dan Nurhaeda (2017) menjelaskan manfaat kelor dalam bidang kesehatan salah satunya sebagai anti diabetes. Daun kelor memiliki sifat anti diabetes yang berasal dari kandungan seng yang tinggi seperti mineral yang sangat di butuhkan untuk memproduksi insulin, sehingga daun kelor dapat bermanfaat sebagai anti diabetes yang signifikan. Daun kelor mengandung zat besi lebih tinggi daripada sayuran lainnya yaitu sebesar 17,2 mg/100g (Yameogo et el., 2011 dalam Aminah, dkk. 2015). Krisnadi (2015) menjelaskan bahwa M. oleifera mengandung 46 jenis antioksidan kuat, senyawa yang melindungi tubuh terhadap efek merusak tubuh dari radikal bebas dengan menetralkannya sebelum dapat menyebabkan kerusakan sel dan menjadi penyakit

Pendapat lain menjelaskan bahwa salah satu kandungan daun kelor yang tinggi ialah flavonoid. Golongan senyawa ini, terutama glikosidanya mempunyai gugus-gugus gula. Glikosida flavonoid yang terkandung dalam daun kelor tersebut bertindak sebagai penangkap radikal hidroksil, sehingga dapat mencegah aksi diabetonik dari aloksan (Dewiyati dan Hidayat, 2015). Kandungan saponin pada kelor juga dapat membantu penuruann kadar glukosa darah (Shabilla, 2012 dalam Nurlaela, dkk.2016).

Hasil penelitian ini memperkuat hasil penelitian sebelumnya. Nurlaela, dkk. (2016) menunjukkan pemberian ekstrak daun kelor Moringa oleifera Lamk. efektif menurunkan kadar glukosa darah pada mencit Mus musculus L., ekstrak daun kelor dengan pemberian 0,1 mL/10g BB lebih efektif menurunkan kadar glukosa darah pada mencit Mus musculus L. jantan sedangkan pemberian ekstrak daun kelor 0,2 dan 0,3 mL/10g BB lebih efektif dalam menurunkan kadar glukosa darah pada mencit betina. Jaiswal (2009) menjelaskan bahwa hasil uji pengaruh ekstrak daun kelor (Moringa oleifera) terhadap hyperglicemic pada tikus telah memvalidasi secara ilmiah penggunaan $M$. Oleifera yang banyak diklaim sebagai ethnomedicine untuk mengobati diabetes melitus. Kandungan senyawa flavonoid dalam bentuk terpenoid yang terdapat pada kelor merupakan senyawa yang sangat efektif dan lebih aman dalam penurunan kadar gula darah dibanding obat kencing manis yang biasa diresepkan dokter (Dewiyeti dan Hidayat, 2015).

Ekstrak daun kelor dari hasil penelitian ini, memiliki kemampuan dalam menurunkan glukosa darah. Dengan demikian, esktrak daun kelor dapat menjadi obat alternatif yang sangat berguna bagi masyarakat khususnya masyarakat golongan menengah ke bawah. Kemampuan kelor dalam menurunkan kadar gula darah, sebagaimana yang dijelaskan oleh Adisakwattana \& Chanathong (2011) dalam Alathea dan Ramadhian (2015), kelor memiliki aktivitas antihiperglikemik dengan menghambat enzim $\alpha$-glucosidase yang terdapat pada brush border usus halus. Penghambatan pada enzim $\alpha$-glucosidase menyebabkan penurunan laju pencernaan karbohidrat menjadi monosakarida yang dapat diserap oleh usus halus, sehingga menurunkan hiperglikemia postpandrial. Penurunan hiperglikemia postpandrial berkontribusi pada menurunnya kadar hemoglobin $\mathrm{A} 1 \mathrm{C}$ (HbA1C) pada pasien diabetes yang juga menurunkan resiko komplikasi vaskular. Konsumsi ekstrak daun kelor yang memiliki efek menurunkan absorbsi glukosa ke dalam darah pada pasien prediabetik dapat membantu untuk mencegah terjadinya diabetes mellitus tipe 2. Prinsip yang diyakini saat ini, bahwa ekstrak M. oleifera 
mampu meningkatkan sekresi insulin yang diinduksi oleh peningkatan glukosa darah pada sel beta-langerheas yang masih fungsional, yang pada akhirnya menyebabkan penurunan glukosa darah (Gupta \& Gupta, 2009; Gupta et el., 2012 dalam Alathea dan Ramadhani, 2015). Flavonoid yang terkandung dalam $M$. oleifera mampu bekerja sebagai insulin sekretagog atau insulinmimetik, yang akhirnya meminimalisir komplikasi diabetes. Penelitian mengenai senyawa fitokimia pada $M$. oleifera menunjukkan bahwa senyawa bioflavonoid yang terkandung dalam M. oleifera juga berperan dalam stimulasi uptake glukosa di jaringan perifer sehingga mampu menurunkan glukosa dalam darah (Gupta, et el., 2011 dalam Alathea dan Ramadhani 2015).

\section{Kesimpulan}

Mengacu pada tujuan dan hasil serta pembahasan yang telah dijelaskan sebelumnya, maka kesimpulan yang dapat ditarik dari penelitian ini adalah Ekstrak daun kelor (Moringa oleifera Lamk.) efektif dalam menurunkan kadar glukosa darah, khususnya pada tikus (Rattus novergicus), yang ditunjukkan oleh nilai probabiltas signifikan analisis sidik ragam (anava) sebesar $0,000<\alpha(0,05)$. Konsentrasi ekstrak daun kelor (M. oleifera) yang paling efektif dalam menurunkan kadar glukosa darah, khususnya pada tikus (Rattus novergicus) adalah pada perlakuan M4 yaitu konsentrasi esktrak 70\%, dengan nilai hasil uji Duncan yang berbeda dari lainnya, yaitu sebesar 113,40.

\section{Ucapan Terima Kasih}

Ucapan terima kasih kepada laboran dan staf Laboratorium Biologi Fakultas Keguruan dan Ilmu Pendidikan Universitas Tadulako yang telah membantu penulis dalam merampungkan penelitian ini.

\section{Referensi}

Alethea, T \& Ramadhian, M. R. (2015). EfekAntidiabetik pada Daun Kelor). Majority, 4 (4), 118122.

Aminah, S., Ramdhan, T., \& Yanis, M. (2015). Kandungan Nutrisi dan Sifat Fungsional Tanaman Kelor (Moringa oleifera). Buletin Pertanian Perkotaan, 5 (2), 35-44.

Ashfak, M., Shahzad, M. A., Basra \& Ashfaq, U. (2012). Moringa: A Miracle Plant for Agro-forestry. Journal of Agriculture \& Social Science, 8 (3).

Dewiyati, S \& Hidayat, Saleh. (2015). Ekstrak Daun Kelor (Moringa oleifera Lamk.) sebagai Penurun Kadar Glukosa Darah Mencit Jantan Mus musculus L.). Jurnal Penelitian Sains, 17 (2), $72-77$.

Krisnadi, A. D. (2015). Kelor Super Nutrisi (e-book). Blora: Pusat Informasi dan Pengembangan Tanaman Kelor Indonesia Lembaga Swadaya Masyarakat Media Peduli Lingkungan (LSMMEPELING).

Lina, M. (2012). Daun Ajaib Tumpas Penyakit. Jakarta. Penebar Swadaya.

Melo, N. V., Vargas, T., Quirino dan Calvo, C. M. C. (2013). Moringa oleifera L. An Underutilized Tree with Macronutrients for Human Health. Journal Food Agric, 25 (10), 785-789. 
Nurlaela, Hs., Suhadiyah,S., Eva, J. \& Hasyim, Z. (2016). Uji Efektivitas Ekstrak Daun Kelor Moringa oleifera Lamk. Terhadap Penurunan Kadar Glukosa Darah pada Mencit Mus musculus L. Online, melalui http:///repository.unhas.ac.id/handle/123456789/19201show=full (Diakses Tanggal 01 Januari 2019).

Nweze, N. O., \& Nwafor, F. I. (2014). Phytochemical, Proximate and Mineral Composition of Leaf Extracts of Moringa oleifera Lam. from Nsukka, South-Eastern Nigeria. IOSR Journal of Pharmacy and Biological Sciences, (9), 99 - 103.

Shiriki, D., Igyor, M. A. \& Gernah, D. I. (2015). Nutritional Evaluation of Complementary Food Formulations from Maize, Soybean and Peanut Leaf Powder. Food and Nutrition Sciences, (6), $494-500$.

Simbolan, J. M., Simbolan, M. \& Katharina, N. (2007). Cegah Malnutrisi dengan Kelor. Yogyakarta. Kanisius.

Sugihartini, N \& Nuryanti, E. (2017). Formulasi Krim Ekstrak Daun Kelor (Moringa oleifera) sebagai Sediaan Antiaging. Periodical of Dermatology and Venereology, 29, (1), 1-7.

Suhartono, E. Fujiati, Aflanie, I. (2002). Oxygen Toxicity by Radiation and Effect of Glutamic Piruvat Transamine (GPT) Activity Rat P lasma After Vitamine C Treatmen, Diajukan pada Internatinal seminar on Environmental Chemistry and Toxicology. Yogyakarta

\begin{tabular}{|l|l|}
\hline Mursito, $\boldsymbol{S}$ & $\begin{array}{l}\text { M.Pd., Dr. Dosen Universitas Tadulako, Palu, Indonesia } \\
\text { E-mail: mursitobiologi@yahoo.co.id }\end{array}$ \\
\hline Bialangi Lilies & $\begin{array}{l}\text { M.P., Dr. Dosen Universitas Tadulako, Palu, Indonesia } \\
\text { E-mail: liliestangge@yahoo.co.id }\end{array}$ \\
\hline Hayyatun Mawaddah & $\begin{array}{l}\text { S.Pd., M.Pd. Dosen Universitas Tadulako, Palu, Indonesia } \\
\text { E-mail: } \text { mawaddahbio78@gmail.com }\end{array}$ \\
\hline
\end{tabular}

